\title{
Rat dental pulp tissue reaction after capped with propolis derived non flavonoid extract
}

\author{
Ardo Sabir* \\ *Department of Conservative Dentistry Faculty of Dentistry Universitas Hasanudin
}

\begin{abstract}
Propolis is a resinous material collected by honey bees from various plants. Many researches have showed that it has antibacterial and anti-inflammation activities. Flavonoid is the main chemical substance in propolis that inhibits bacterial growth and reduces the release of free radicals, suggesting that this component has anti-bacterial and anti-inflammatory properties. However, there is another chemical substance in propolis that shows antibacterial dan anti-inflammatory activities. The purpose of the present study was to assess the rat dental pulp tissue reaction after capped with propolis derived non-flavonoids extract. Non-flavonoids substances were purified from an ethanol extract of propolis obtained from South Sulawesi, Indonesia. A Class I cavity was prepared on the occlusal surface of the right maxillary first molar in Spraque-Dawley rats. The dental pulp was exposed and then capped with a zinc oxide-based filler as a control (Group I), or non-flavonoids propolis (Group II). Then, each cavity was filled with glass ionomer cement. The animals were sacrificed at week 1,2 , or 4 . Biopsy samples were obtained, and these were stained and viewed by light microscopy. The histological examination was based on the presence of polymorph nuclear leukocytes and macrophages. The results showed that pulp inflammation occured in both group as early as week 1 . However, the inflammation occured in Group II was relatively milder compared to Group I at all time period. Therefore, present results suggest that application of non-flavonoids propolis extract on rat's dental pulp tissue might inhibit inflammatory process.
\end{abstract}

Key words: Non-flavonoid, propolis, dental pulp, rat

\section{ABSTRAK}

Propolis adalah suatu bahan resin yang dikumpulkan oleh lebah madu dari berbagai jenis tumbuhan. Banyak penelitian telah memperlihatkan bahwa propolis memiliki aktivitas antibakteri dan anti-inflamasi. Flavonoid merupakan substansi kimia utama dalam propolis yang menghambat pertumbuhan bakteri dan mengurangi terlepasnya radikal bebas sehingga substansi ini diduga memiliki sifat antibakteri dan anti-inflamasi. Namun demikian, terdapat substansi kimia lain dalam propolis yang mungkin memperlihatkan aktivitas antibakteri dan anti-inflamasi. Tujuan penelitian ini adalah untuk menilai reaksi jaringan pulpa gigi tikus setelah diaplikasikan dengan ekstrak non-flavonoid dari propolis. Substansi non-flavonoid dipurifikasi dari ekstrak etanol propolis yang diperoleh dari Provinsi Sulawesi Selatan, Indonesia. Suatu kavitas Klas I dipreparasi pada permukaan oklusal gigi molar pertama 
kanan rahang atas tikus Spraque-Dawley. Pulpa gigi diperforasi kemudian diaplikasikan dengan bahan berbasis zinc oxide sebagai kontrol (kelompok I) atau ekstrak non-flavonoid propolis (kelompok II). Setiap kavitas kemudian ditumpat dengan semen glass ionomer. Hewan coba dikorbankan 1, 2, atau 4 minggu setelah perlakuan. Biopsi dari sampel diperoleh, kemudian dilakukan pengecatan dan dilihat dengan menggunakan mikroskop cahaya. Pemeriksaan histologis didasarkan pada adaltidaknya sel leukosit polimorfonukleus dan sel makrofag. Hasilnya memperlihatkan bahwa inflamasi pada pulpa terjadi pada kedua kelompok pada minggu ke-1. Namun demikian, inflamasi yang terjadi pada kelompok II relatif lebih ringan dibanding kelompok I pada semua periode waktu. Oleh karena itu hasil penelitian ini menunjukkan bahwa aplikasi ekstrak non-flavonoid propolis pada jaringan pulpa gigi tikus mampu menghambat proses inflamasi.

Kata kunci: non-flavonoid, propolis, pulpa gigi, tikus.

\section{INTRODUCTION}

Inflammation is a protective response intended to eliminate the initial cause of cell injury. Inflammation is divided into two basic pattern, acute inflammation and chronic inflammation. Acute inflammation is of relatively short duration, lasting from a few minutes up to a few days, and is characterized by fluid and plasma protein exudation and a predominantly neutrophilic (PMN leukocyte) accumulation. Chronic inflammation is of longer duration (days to years) and is typified by influx of lymphocytes and macrophages. ${ }^{1}$

Propolis (bee glue, or royal jelly) is a natural resin of pines substance, collected by bees. The term 'propolis' derives from 'pro' (Greek=before), and 'polis' (city) based on the fact that honeybees use propolis to narrow the opening to their hives. Propolis is a complex entity, containing about 55\% resinous compounds and balsam, 30\% beeswax, $10 \%$ ethereal and aromatic oils, and $5 \%$ bee pollen. Contained chemicals include amino acids; flavanoids including flavones; flavonols and flavanones; terpenes; vanillin; tetochrysin; isalpinin, pinocembrin, chrysin, galangin; ferulic acid; caffeic acid; caffeic acid, phenethyl ester; cinnamic acid, and cinnamyl alcohol. ${ }^{2}$

Flavonoids are well-known as main compound in propolis that inhibit bacterial growth, reduce the release of free radicals, and regulate the immune response, suggesting that this component has natural anti-bacterial, anti-inflammatory and immuno-regulatory properties. ${ }^{3,4}$ However, there is another chemical substance in propolis that might show antibacterial dan anti-inflammatory activities. ${ }^{5}$ Therefore, the purpose of the present study was to assess the rat dental pulp tissue reaction after capped with propolis derived non-flavonoids extract.

\section{METHODS}

This study was an experimental laboratory research with a random post test only control group design. The study was conducted at Biology Pharmacy Laboratory, Faculty of Pharmacy; Experimental Animal Breeding Unit, Faculty of Veterinary; and Histology and Cell Biology Laboratory, Faculty of Medicine, Gadjah Mada University Yogyakarta. Propolis (Trigona sp.) was collected from honeycombs in Bulukumba Regency, South Sulawesi in the early monsoon season. Nonflavonoids propolis extract was obtained by dried propolis subjected to exhaustive maseration, filtered using aqueous ethanol, and concentrated using a rotary evaporator. The residue was separated using aqueous ethanol and toluene solution with proper ratio to yield non-flavonoid fraction.

Eighteen male Sprague-Dawley rats of 8-16 week old and 200-250 grams weight were divided into two groups randomly and equally. Group I as control group, zinc oxide-based filler (Dentorit ${ }^{\mathbb{}}$, Dentoria, France) was directly applied on pulp exposure. Meanwhile in Group II, as the sample group, pulp exposure was applied with NFP extract. The rats were anesthetized intramuscularly with ketamine (Ketalar ${ }^{\oplus}$, Warner Lambert, Ireland) (65 $\mathrm{mg} \mathrm{kg}^{-1}$ body weight) and xylazine- $\mathrm{HCl}$ (Rompun ${ }^{\oplus}$, Bayer, Leverkusen, Germany) (7 $\mathrm{mg} \mathrm{kg}^{-1}$ body weight). A Class I cavity was prepared on the occlusal surface of the right maxillary first molar 
in Spraque-Dawley rats. The pulp exposures were performed using a low-speed tapered round diamond bur (Intensiv ${ }^{\oplus}$, Switzerland) $(0.84 \mathrm{~mm}$ in diameter) and directly lined with zinc oxidebased filler $(0.5 \mathrm{mg})$ or propolis derived nonflavonoids extract $(0.5 \mathrm{mg})$. Each cavity was then air-dried and filled with glass ionomer cement (Fuji IX ${ }^{\circledast}, G C$, Tokyo, Japan) as permanent filling. The experimental protocol was approved by the ethical committee of Faculty of Medicine, Gadjah Mada University, Yogyakarta.

Three rats were sacrificed at week 1,2 , or 4 respectively. The teeth and the surrounding bones were resected, fixed in 10\% neutral buffered formalin for 4 days, and then decalcified with $10 \%$ Ethylene Diamine Tetraacetic Acid (EDTA) for 30 days, embedded in paraffin and sectioned serially at $6 \mu \mathrm{m}$ thickness. The sections were stained with hematoxylin-eosin and viewed by light microscopy. Histological assessment of the slides was made according to the presence or absence of polymorphonuclear leukocytes (PMNL) and/or macrophages and was graded as follows: $0=$ No infiltration of inflammatory cells; $1=$ Infiltration by a few PMNL, and/or macrophages (mild inflammation); 2 = Infiltrated by a moderate number of PMNL, and/or macrophages (moderate inflammation); and 3 = Massive infiltration of PMNL and/or macrophages (severe inflammation).

\section{RESULTS}

Response of inflammation on rat's dental pulp after application of zinc oxide-based filler or propolis derived non-flavonoids extract can be seen in Table 1 and Figure 1.

From Table 1, it seems that in Group I, mild and moderate inflammation was evident in pulp chamber at week 1 and the levels of inflammatory response tend to increase at $2^{\text {nd }}$ and $4^{\text {th }}$ week (moderate and severe inflammation). In contrast, in Group II, only mild inflammation was evident

Table 1. Response of inflammation on rat's dental pulp after application with zinc oxide-based filler or propolis derived nonflavonoids extract

\begin{tabular}{clccccc}
\hline \multirow{2}{*}{$\begin{array}{c}\text { Time period } \\
\text { (weeks) }\end{array}$} & \multirow{2}{*}{ Groups } & \multirow{2}{*}{$\begin{array}{c}\text { Specimen } \\
(\mathrm{n})\end{array}$} & & \multicolumn{4}{c}{ Inflammation response } \\
\cline { 5 - 7 } & & None & Mild & Moderate & Severe \\
\hline 1 & I (zinc oxide) & 3 & - & 2 & 1 & - \\
& II (NFP) & 3 & - & 3 & - & - \\
2 & I (zinc oxide) & 3 & - & - & 2 & 1 \\
\multirow{2}{*}{4} & II (NFP) & 3 & - & 2 & 1 & - \\
& I (zinc oxide) & 3 & - & - & 1 & 2 \\
& II (NFP) & 3 & - & 1 & 2 & - \\
\hline
\end{tabular}

Note : NFP (Non-flavonoids propolis) extract
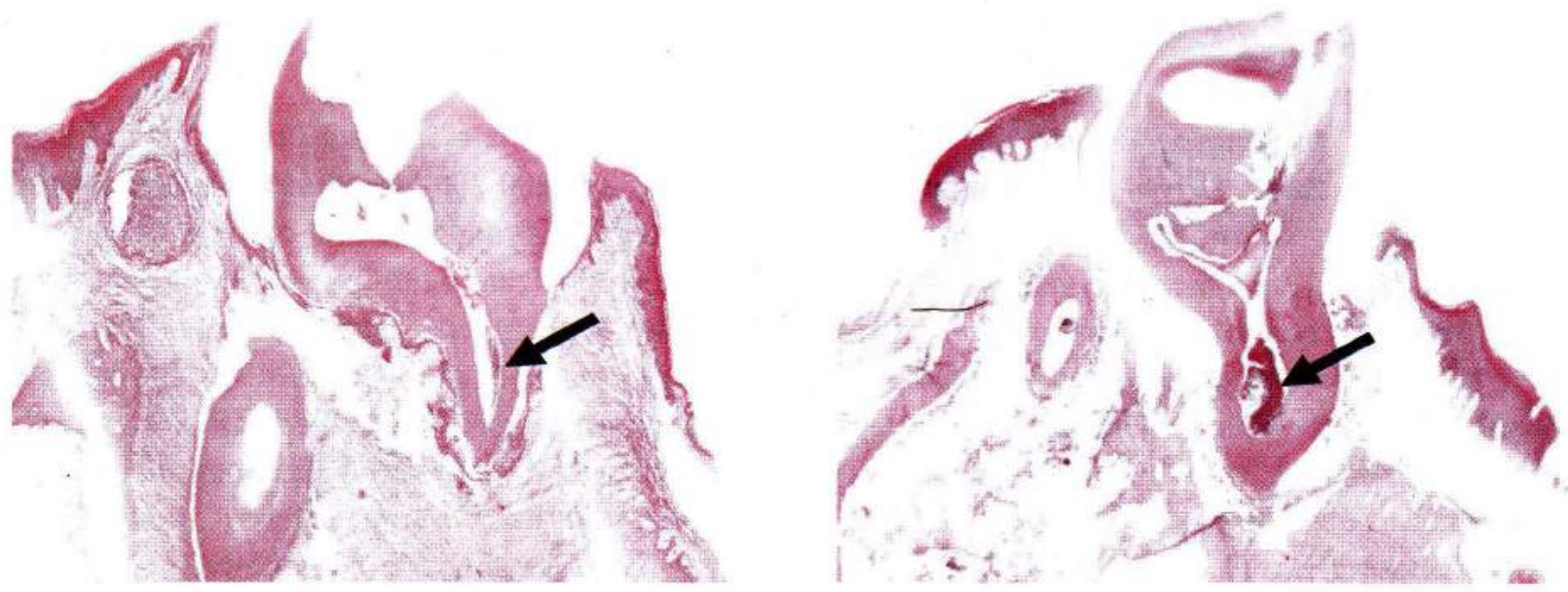

Figure 1. Histological evaluation of rat's dental pulp response after application with propolis derived non-flavonoids extract. (A) Only mild inflammatory response occured in dental pulp chamber at $1^{\text {st }}$ week; (B) Moderate inflammatory response was occured in dental pulp chamber at $4^{\text {th }}$ week. Arrows show inflammatory cells (Hematoxylin-eosin stain, original magnification $40 x$ ). 
in all specimen which treated with non-flavonoids propolis extract at $1^{\text {st }}$ week (Fig. 1A). However, a moderate inflammatory response occurred in 1 out of 3 animals at $2^{\text {nd }}$ week. Meanwhile, at $4^{\text {th }}$ week, a moderate inflammatory response was also seen in pulp chamber of 2 animals from this group (Fig. 1B). No evidence of necrotic pulp tissue was seen in both groups throughout the study.

For the sake of clarity and brevity, the photomicrographs of histological evaluation is presented here only by the section from Group II at $1^{\text {st }}$ and $4^{\text {th }}$ week (Fig. 1).

\section{DISCUSSION}

The present study showed that application of non-flavonoid materials extracted from propolis on rat dental pulp showed only mild inflammatory response. In contrast, zinc-oxide stimulated not only mild inflammatory response but also moderate inflammatory response 1 week after application. Several studies have reported the suppression of inflammation process by propolis from different geographic locations. ${ }^{6,7}$ The antiinflammatory activity of propolis not only depends on polyphenolic compounds (flavonoid aglycones), but also by additional active compounds, such as ferulic acid, (hydroxyl) cinnamic acid and diterpene derivatives. ${ }^{5}$

The exact mechanism of propolis derived non-flavonoid extract to inhibit bacteria was not fully understood. However, Šimuth et al. ${ }^{8}$ reported that several substances in propolis which are able to absorb UV light inhibiting the DNA-dependent RNA polymerase as well as the restriction endonuclease. The inhibition of bacterial RNApolymerase by the components of propolis was probably due to the loss of their ability to bind to DNA.

As seen at Figure $1 \mathrm{~A}$, at $1^{\text {st }}$ week in Group II, only a few PMNL or macrophage cells could be found in the dental pulp chamber after lined directly with propolis derived non-flavonoids extract. In contrast, at $4^{\text {th }}$ week there was numerous of macrophage cells with moderate density could be seen in this group (Fig. 1B). The exact mechanism responsible for this chronic inflammatory response which occurred at $4^{\text {th }}$ week in Group is II still unknown and needs to be further clarified. However, several possible explanations can be considered, including oral bacterial microleakages that might not have been completely eliminated by propolis derived non-flavonoids extract. Alternatively, both the anti-inflammatory and anti-bacterial properties of propolis derived non-flavonoids extract might have been considerably reduced at week 4 due to metabolisms of this materials. ${ }^{10}$

The present study has shown that propolis derived non-flavonoids extract showed slight dental pulp inflammatory process in rats at $1^{\text {st }}$ week. However, moderate pulp inflammation was evident at $2^{\text {nd }}$ and $4^{\text {th }}$ week. In contrast, after application with a zinc oxide-based filler, there was slight and moderate inflammation at $1^{\text {st }}$ week and increased at $2^{\text {nd }}$ and $4^{\text {th }}$ week.

\section{CONCLUSION}

The present results obtained in rats suggest that application of propolis derived non-flavonoids extract on rat's dental pulp might delay pulp inflammation process.

\section{ACKNOWLEDGEMENTS}

The author thank to Dr. S. Pramono (Faculty of Pharmacy, Gadjah Mada University, Yogyakarta) for assistance in propolis preparation.

\section{REFERENCES}

1. Mitchell RN, Cotran RS. Acute and chronic inflammation. In: Kumar V, Cotran RS, Robbin SL, editors. Basic pathology. $7^{\text {th }}$ ed. Philadelphia: WB Saunders Co.; 2003. p. 334.

2. Scully C. Propolis: A background. Br Dent J 2006;200:359-60.

3. Kosalec I, Pepeljnjak S, Bakmaz M, VladimirKnezević S. Flavonoid analysis and antimicrobial activity of commercially available propolis products. Acta Pharm 2005;55(4):423-30.

4. Parolia A, Thomas MS, Kundabala M, Mohan M. Propolis and its potential uses in oral health. Int J Med Med Sci 2010;2(7):210-5.

5. Borrelli F, Maffia P, Pinto L, Ianaro A, Russo A, Capasso F, et al. Phytochemical compounds involved in the anti-inflammatory effect of propolis extract. Fitoterapia 2002;73(5):53- 
63.

6. Velazquez C, Navarro M, Acosta A, Angulo A, Dominguez Z, Robles R, et al. Antibacterial and free-radical scavenging activities of Sonoran propolis. Appl Microbiol 2007;103:1747-56.

7. Sabir A. Respons inflamasi pada pulpa gigi tikus setelah aplikasi ekstrak etanol propolis (EEP). Majalah Kedokteran Gigi (Dent J) 2005;38(2):77-83.

8. Simuth J, Trnovsky J, Jeloková J. Inhibition of bacterial DNA-dependent RNA polymerases and restriction endonuclease by UV-absorbing components from propolis. Pharmazie 1986;41:131-2.

9. Murray PE, Hafez AA, Windsor LJ, Smith AJ, Cox CF. Comparison of pulp responses following restoration of exposed and nonexposed cavities. J Dent 2002;30:213-22.

10. Havsteen $\mathrm{BH}$. The biochemistry and medical significance of flavonoids. Pharmacol Ther 2002;96:67-202. 